\title{
Configurações
}

Revista de sociologia

9 | 2012

Trabalho e género: vidas precárias, percursos e acção colectiva

\section{Estou aqui por recear o meu futuro. Juventude, precariedade e protesto}

I'm here for fear of my future. Youth, precariousness and protest

Je suis ici par crainte de mon avenir. Jeunesse, précarité et protestation

\section{José Soeiro}

\section{OpenEdition \\ Journals}

\section{Edição electrónica}

URL: http://journals.openedition.org/configuracoes/1140

DOI: $10.4000 /$ configuracoes. 1140

ISSN: 2182-7419

\section{Editora}

Centro de Investigação em Ciências Sociais

\section{Edição impressa}

Data de publição: 30 Junho 2012

Paginação: 103-119

ISSN: 1646-5075

\section{Refêrencia eletrónica}

José Soeiro, "Estou aqui por recear o meu futuro. Juventude, precariedade e protesto », Configurações [Online], 9 | 2012, posto online no dia 27 novembro 2013, consultado o 19 abril 2019. URL : http:// journals.openedition.org/configuracoes/1140; DOI : 10.4000/configuracoes.1140

Este documento foi criado de forma automática no dia 19 Abril 2019.

(c) CICS 


\title{
Estou aqui por recear o meu futuro. Juventude, precariedade e protesto
}

\author{
I'm here for fear of my future. Youth, precariousness and protest \\ Je suis ici par crainte de mon avenir. Jeunesse, précarité et protestation
}

\author{
José Soeiro
}

\section{0 arrepio Deolinda e a "geração perdida"}

1 No dia 23 de Janeiro de 2011, no Coliseu do Porto, o grupo musical português Deolinda ${ }^{1}$ apresentava, no final de um concerto que havia enchido a sala, um tema novo que de imediato provocou uma reação emocionada e entusiástica do público: "Parva que Sou". Nos dias que se seguiram, o vídeo dessa música ${ }^{2}$, colocado no youtube por uma das pessoas que assistiu ao espetáculo, atingiu dezenas de milhar de visualizações. Transformando-se num fenómeno viral, a canção, partilhada incessantemente nas redes sociais, provocou um debate público intenso sobre o emprego dos jovens, a generalização da condição precária e os contornos da vivência juvenil no nosso país. "Parva que Sou" inspirou ainda a convocação de uma manifestação "laica, apartidária e pacífica", organizada a partir de um evento de Facebook, criado por quatro jovens que pareciam personificar a situação descrita pela música. Esse protesto viria a acontecer em mais de uma dezena de cidades, juntando cerca de 300 mil pessoas em Lisboa e 80 mil no Porto, segundo os organizadores.

Cerca de um mês antes do concerto do Coliseu, num outro ponto do mundo, um jovem trabalhador precário, Mohamed Bouazizi, vendedor ambulante de 26 anos, ateava fogo a si próprio em desespero. Depois de não conseguir licença para trabalhar na rua e de, em função disso, ser assediado pelas autoridades tunisinas, a quem não conseguia continuar a pagar os subornos, acabou por ter a sua mercadoria e a sua balança confiscadas. $\mathrm{O}$ fogo não o matou nesse dia e o seu exemplo, que se tornou notícia, inspirou protestos e outras ações idênticas na Tunísia. Bouazizi acabaria por morrer a 4 de Janeiro - mas o regime de Bem Ali tinha também os dias contados. 
3 Entre o concerto do Coliseu e o protesto da Geração à Rasca ${ }^{3}$, que aconteceu a 12 de Março, houve um outro acontecimento que se difundiu pelo mundo árabe e pela Europa. As imagens do protesto dos egípcios contra a ditadura, muitos deles jovens e insatisfeitos não apenas com a repressão mas com o desemprego e a precariedade no seu país, correram mundo. Esse movimento, aparentemente espontâneo, aparentemente sem partidos ou sindicatos por detrás, seria o prelúdio da uma revolução cujos resultados ainda não são evidentes e cujos impactos ultrapassaram em muito o Egito ${ }^{4}$.

4 Menos de dois meses depois da primeira ocupação da praça Tahrir, teve lugar em Portugal uma das maiores manifestações da nossa história recente, a da "Geração à Rasca". A precariedade dos jovens, mas também as críticas às instituições políticas e económicas, ocuparam nesse dia a rua e foram objeto de debate e de confronto entre discursos, representações e leituras da realidade contrastantes. O restante período do ano de 2011 foi rico em mobilizações sociais que "partiram à reconquista do espaço público, mediático e político" (Davis, 2012), das acampadas dos Indignados em Madrid ou Barcelona (Taibo, 2011; Viejo, 2011) ao movimento Occupy nos Estados Unidos (que se estendeu bem para além de Wall Street) ${ }^{5}$, dos tumultos ingleses às manifestações na Grécia ou ao protesto dos jovens pelo direito à habitação em Israel. A praça, a rua e a figura do manifestante voltaram ao centro da política.

5 No relatório sobre as tendências do emprego para a juventude publicado em 2011 pela Organização Internacional do Trabalho (OIT), esta agência refere-se aos jovens de hoje como uma "geração perdida". Com a generalização de formas precárias de emprego, com taxas de desemprego jovem a rondar os $25 \%$ no Norte de África e os $18 \%$ na Europa (41,6\% em Espanha), com a disseminação da pobreza assalariada (onde os jovens surgem de forma desproporcionada: 23,5\%) e com os jovens a constituírem já a maioria dos desempregados de longa duração, a OIT salienta que os protestos que em 2011 tiveram lugar no Norte de África mas também em Espanha, Inglaterra ou Grécia, encontram aqui a sua raiz fundamental (OIT, 2011: 3 -6). Com efeito, como destaca o mesmo documento, têm sido os jovens a pagar o preço mais alto em termos de emprego ao longo da crise que se instalou desde 2008 e isso justifica que "se sintam desanimados sobre o futuro" e até "irritados" e "violentos" (idem: 6). Um ano depois, o mesmo organismo apontava a extensão do desemprego juvenil a 75 milhões, enfatizando que "muitos jovens estão encurralados" num tipo de trabalho que "não corresponde às suas aspirações e frequentemente não oferece oportunidades de transição para posições mais permanentes, produtivas e bem remuneradas" (OIT, 2012: 8).

6 O desafio deste artigo é problematizar as origens e as dimensões deste fenómeno, concentrando -se sobre a realidade portuguesa. Tentaremos, primeiro, perceber como se insere a precarização na transformação do capitalismo. Depois, procuramos abordar os traços de uma tipicidade juvenil, rejeitando todavia a abordagem da "guerra geracional". Por último, deixamos algumas considerações sobre as experiências de ação colectiva que têm surgido.

\section{Precariedade, a "grande transformação"}

O desemprego estrutural e a precariedade instalaram-se como um regime permanente e como a tendência dominante de evolução do capitalismo (Castel, 2009: 54). É óbvio que a noção de precariedade é, muitas vezes, ambígua e comporta múltiplos sentidos. Kovács, 
por exemplo, tem chamado a atenção para a diversidade de trajetórias de flexibilidade de emprego (qualificante, precarizante transitória ou precarizante a longo prazo) e para a importância de ter em conta essa diferença (Kovács, 2005: 42 -43). Outros, como Paugam (2000), têm procurado operacionalizar empiricamente o conceito, associando a noção de precarização quer às características do emprego e do seu vínculo jurídico, quer às condições técnico -materiais e à qualidade dos enquadramentos organizacionais do trabalho. Contudo, quando aqui recorremos à noção de precarização, ela pretende designar uma das tendências mais fortes da "grande transformação" (para retomar a expressão celebrizada por Karl Polanyi ${ }^{6}$ ) que está em curso no regime do capitalismo, que afeta as suas formas de produção, de troca e o seu modo de regulação (Castel, 2009).

8 A etapa do capitalismo que hoje atravessamos corresponde a um processo de reestruturação produtiva que ainda não encerrou o seu ciclo e que tem como base a necessidade do capital "garantir a acumulação, porém de modo cada vez mais flexível e compatível com a nova fase" (Antunes, 2008). Ao contrário do que historicamente caracterizou a fase anterior - o fordismo - a dinâmica deste novo regime do capitalismo é de remercantilização, descoletivização e reindividualização do trabalho. Ela manifesta-se no plano organizacional: individualização das tarefas, mobilidade, adaptabilidade dos trabalhadores, subcontratação, emagrecimento das empresas em pequenas unidades, intermitência, dispensa das convenções de trabalho. Mas exprime -se também no plano das trajetórias profissionais, que sofrem as consequências da desestabilização do emprego e da sua progressiva desinscrição em regulações colectivas, emergindo uma espécie de "modelo biográfico" (Beck, 1992) em que as carreiras se tornam mais fluidas e descontínuas. Paradoxalmente, ao mesmo tempo que se exalta como nunca o sujeito, assiste-se à possibilidade de desqualificação do indivíduo pela ausência de recursos que permitam à maioria conduzir os seus projetos e fazer as suas escolhas.

9 A "grande transformação" de que vimos falando constitui uma mudança profunda da condição salarial, erodindo a forma hegemónica que assumiu sob o capitalismo industrial (Castel, 2009: 161). É provável que os jovens sejam hoje as principais vítimas dessa erosão, mas ela pretende-se global. Por outro lado, esta transformação tem significado também uma nova narrativa do capitalismo e dos seus dispositivos de legitimação ideológica e de justificação moral. Estes passam a assentar numa retórica em que a mudança e a mobilidade são salientadas de forma apologética como formas de libertação do indivíduo face a constrangimentos burocráticos. Como explicam Boltanski e Chiapello (1999) o "novo espírito do capitalismo" soube recuperar os termos da crítica expressiva que lhe eram dirigidos e apresentar-se com uma narrativa de libertação. Incorporou, distorcendo -as, as ideias de liberdade e de autonomia. O reforço da "autonomia" foi transformado em mais autocontrolo (trabalho em equipa, controlo informático...) e a menor segurança no trabalho apresentada como condição de "liberdade". 0 culto da performance, a exaltação da mobilidade e a emergência de um modelo conexionista são características maiores deste seu "novo espírito".

10 É interessante perceber ainda como, neste contexto, o trabalho é apresentado cada vez mais como uma série de infinitas atividades e cada vez menos como "emprego". Com efeito, assistimos hoje à apologia de uma sociedade de "plena atividade", sem que isso corresponda a uma sociedade de "pleno emprego". Como defende Castel (2009), existe simultaneamente um crescimento do não-emprego (situações que significam que as pessoas não terão oportunidade de regressar ao mercado de trabalho) e do subemprego (precário, informal); uma retórica de valorização do trabalho que o apresenta como um 
imperativo e como a única forma de respeitabilidade social; e uma estigmatização dos que não têm trabalho como "ociosos" ou "maus pobres" (veja -se em Portugal, por exemplo, o anátema sobre os beneficiários do Rendimento Social de Inserção ${ }^{7}$ ). Esses três factores combinados contribuem para o elogio de um futuro que se quer de "plena atividade", sem que haja uma política de "pleno emprego". Ou seja, a exaltação deste "novo espírito do trabalho" acaba por constituir uma fortíssima pressão para a aceitação de qualquer tipo de atividade, mesmo sem os direitos associados ao emprego (Castel, 2009: 118 -119). A crise financeira iniciada em 2007/2008, e a sua transmutação em crise das dívidas soberanas, tem sido um pretexto para aprofundar este processo, particularmente nos países do Sul da Europa.

11 Em Portugal, as tendências de desenvolvimento que são comuns a todo o continente apresentam as particularidades de uma sociedade semiperiférica, em que uma modernização conservadora - que construiu muito recentemente as formas modernas de regulação e proteção laboral - é também marcada pelas políticas neoliberais dominantes nesta fase de globalização. Num conjuntura marcada pela intervenção da Troika (Fundo Monetário Internacional, Banco Central Europeu e União Europeia), a dinâmica de austeridade vem acentuar e acelerar este processo e a lógica de acumulação que lhe preside.

\section{Portugal, sociedade complexa}

12 De acordo com Estanque (2005), coexistem na estrutura produtiva e de relações sociais do nosso país lógicas pré -capitalistas com todo um segmento pós-fordista no mundo da produção e com a disseminação em peso das lógicas da sociedade de consumo. Combinam -se velhas desigualdades com a distribuição assimétrica de novos recursos e as contradições da nossa sociedade agudizam-se pelas impressionantes transformações de que foi alvo nas últimas décadas. Portugal assiste a uma transição problemática em que se ampliam e intensificam processos de estruturação das desigualdades, mais gritantes no contexto desta crise.

13 A mera consideração das tensões entre um pólo fordista e outro pós-fordista, dominante nas análises sociológicas produzidas nos países e sobre os países centrais da Europa, não chega para compreender a nossa estrutura produtiva e os conflitos que dela (não) emergem. Com efeito, o peso da economia informal e subterrânea e a persistência de traços característicos dos regimes pré-fordistas de organização do trabalho não são um mero resquício do passado, mas um factor estrutural e estruturante das relações económicas e sociais em Portugal, justamente responsáveis por uma parte não negligenciável das situações de subemprego e de emprego desprotegido e sem factores de satisfação e reconhecimento ao nível do seu conteúdo (Pinto, 2005). Esta desregulação de facto cria também verdadeiras zonas francas do direito laboral e é uma das "patologias da democracia laboral" em Portugal (Ferreira, 2009).

Entre os jovens, por exemplo, o trabalho informal ou clandestino é um fenómeno de larga escala (Guerreiro e Abrantes, 2007) - são os famosos "ganchos" e "biscates" (Pais, 2001). A precarização desenvolve -se assim, quantas vezes, por via da transgressão dos enquadramentos legais (como no caso dos estágios e dos "recibos verdes", que podem prolongar -se por décadas), num quadro social em que as condições de trabalho são já tradicionalmente precárias e marcadas por inseguranças e ilegalidades várias, o que tem um efeito direto na debilidade no acesso aos direitos associados ao trabalho e na difusão 
do medo de os reivindicar. Kóvacs (2005), que dirigiu um estudo sobre a difusão do emprego flexível em Portugal, inserindo -o comparativamente no contexto europeu, defende que o nosso país tem características próprias que não devem ser ignoradas. Muito esquematicamente, as tendências do mercado de trabalho em Portugal, relativamente a esta questão, podem ser expostas do modo seguinte: um processo galopante de flexibilização, que contraria a retórica sobre a "rigidez" do nosso enquadramento legal ou que se faz à margem da regulação legal existente; uma proporção de contratos de duração temporária superior à média europeia, com uma tendência para a longa duração (ou seja, para substituírem tarefas desempenhadas em permanência e por trabalhadores com vínculo estável); o recurso ao trabalho independente como forma de externalizar certos postos de trabalho e de transferir os riscos para os trabalhadores, proliferando os chamados "falsos recibos verdes"; o aumento abaixo da média europeia do trabalho a tempo parcial, provavelmente devido aos baixos salários praticados no nosso país e à vantagem, para os empregadores, da flexibilização e da redução de custos por via de contratos a termo, trabalho independente e trabalho temporário (diferenciado conforme as situações) das mulheres, dos jovens e dos menos qualificados nesta "via baixa" da flexibilização.

A par da precarização, as profundas mudanças ocorridas criaram também novos segmentos de classe e uma juventude crescentemente escolarizada cujas aspirações são moldadas pelas referências e pelos estilos de vida que constituem o modelo das sociedades de consumo. $\mathrm{O}$ abismo entre expectativas e oportunidades pode ser, assim, gerador de ressentimento e de revolta. No protesto do 12 de março, várias das mensagens dos participantes pareciam exprimir este sentimento: "porque é que os jovens não têm futuro em Portugal?", "queremos os postos de trabalho que disseram que íamos ter", "não quero continuar a viver à custa dos meus pais e trabalhar a recibos verdes, peço muito?", "não me obriguem a emigrar!", "estou aqui por recear o meu futuro", "um dia mando foder isto tudo e baldo -me daqui para fora", "eu quero ter a certeza e ainda só tenho 16 anos, o tempo que ando a estudar vai servir para alguma coisa?".

\section{4. "Tu nesse jogo vales tão pouco" a geração low cost}

16 Se as várias formas de expressão artística constituem, desde sempre, um interessante objecto da sociologia não é apenas pelo que elas revelam sobre o estrito campo artístico (no sentido bourdiano) ou sobre os consumos culturais. É que a comunicação estética, que é a comunicação através dos sentidos, tem frequentemente a capacidade de sintetizar e de exprimir com particular eloquência as redes de sentido e representações que circulam numa dada sociedade. $\mathrm{O}$ fenómeno de "Parva que Sou", uma música cujo tom oscila entre a denúncia, o lamento e a indignação, parece ter conseguido captar elementos cruciais do que é hoje, para um importante segmento da nossa sociedade, a condição juvenil.

Em Portugal, a inserção laboral dos jovens caracteriza -se por ser longa, penosa e complexa. Inserção profissional difícil, trabalho desqualificado apesar da subida das habilitações, falta de correspondência entre qualifi cações e habilitações, precariedade e baixos salários, eis o que a define. De acordo com um estudo realizado em 2011, os jovens têm de esperar em média 20,4 meses desde que terminam a escolaridade até terem o primeiro trabalho com uma duração de pelo menos três meses (CIES/ CGTP -IN, 2011: 7 $-10)^{10}$. O tempo de inserção para um emprego permanente é em média 10 anos desde a saída da escola. 
18 A multiplicação de baixos salários, de situações de estágios não remunerados (em particular em certas áreas qualificadas como o jornalismo, a arquitetura, entre outras) e de formas de precariedade assistida pelo Estado, entre formação e trabalho, permitem que se fale efetivamente numa "geração low cost" (Chauvel, 2008). Em Portugal, ela combina salários baixos - em 2011, mais de metade dos jovens empregados auferia um salário entre os 450 e os 600 euros e mais de $2 / 3$ dos jovens recebia menos de 750 euros (CIES/ CGTP -IN, 2011: 9) - com escassa proteção social. Quando a canção dos Deolinda refere uma "geração sem remuneração", é provavelmente disto que fala. De facto, em Portugal, cerca de $20 \%$ dos jovens vive em risco de pobreza.

19 Se seria eventualmente expectável que, dotados de maiores qualificações, os jovens pudessem estar menos expostos ao desemprego que os mais velhos ${ }^{11}$, a realidade revelanos o contrário. $O$ desemprego entre os jovens é mais do dobro da taxa de desemprego geral (36,4\% em julho de 2012, segundo o Eurostat ${ }^{12}$ ) e não existe uma tendência de aproximação entre as duas taxas. Os jovens são além disso, pela sua inserção precária no trabalho, mais vulneráveis ao ciclo económico. Na realidade, o desemprego de longa duração está a aumentar mais entre os jovens: na faixa etária entre os 25 e os 34 anos, mais de metade do desempregados estava em 2011 sem trabalho há mais de um ano (CIES/ CGTP-IN, 2011). Por outro lado, estão menos protegidos quando ficam sem trabalho vínculos precários, situações de trabalho informal, "falsos recibos verdes" e carreiras contributivas curtas bloqueiam o acesso ao subsídio de desemprego.

20 Chauvel (2008) tem defendido a ideia de que os jovens são hoje vítimas de uma dupla desclassificação: (i) desclassificação do emprego, entendida como a ocupação de um emprego com uma remuneração inferior à que seria expectável dado o seu diploma escolar e (ii) desclassificação salarial, entendida como a quebra da remuneração dentro de uma mesma profissão ao longo dos anos (devido à restrição dos aumentos salariais nas últimas décadas e à perda efetiva de poder de compra). Estas desclassificações têm dimensões objetivas mas também dimensões subjetivas, que assumem por vezes grandes proporções. É o caso, por exemplo, da percepção por parte dos jovens mais escolarizados de que ocupam posições inferiores às expectativas decorrentes das que os seus estudos permitiriam almejar. Este fenómeno tem gerado uma desilusão dupla, face ao incumprimento das promessas quer do mundo de trabalho quer da escola. Alguns grupos sociais vivem com particular sofrimento esta situação, sob a forma de um pessimismo por antecipação, de uma ameaça latente, de um sentimento de ansiedade em relação ao futuro (Goux, Maurin, 2012: 29). Nos protestos da Geração à Rasca, esta realidade teve uma expressão significativa: "eu vim porque não quero andar a estudar para nada", "vim à manifestação porque sou estudante, vejo colegas meus a esforçarem-se para tirar o curso e chegam ao fim e estão no desemprego", "estou aqui porque nos disseram que no futuro iríamos ser recompensados pelo estudo e agora somos obrigados a encontrar soluções fora do nosso país", "merecemos reconhecimento" ${ }^{13}$. Nos casos em que a formação é uma estratégia determinante para um percurso desejado de mobilidade ascendente, a frustração pode ganhar contornos mais fortes: "troco licenciatura por $€$ ", "porquê abrir vagas num curso que não terá saídas? Porque nos criam ilusões??? BASTA", "para estar desempregado não precisava de mestrado", referiam algumas das mensagens dos manifestantes do 12 de março. Trata -se, no fundo, de um efeito do paradoxo identificado pelos Deolinda, o de um "mundo parvo onde para ser escravo é preciso estudar".

21 Estas desilusões são enfrentadas pelos jovens com estratégias opostas: ou a acumulação de diplomas na esperança de que eles invertam o processo de desclassificação (estudar para 
escapar a ser escravo) ou a descrença total, mais ou menos profunda, no sistema de formação ("estudar para quê se não temos emprego?", perguntava -se num cartaz da manifestação) (Dubet, 2008: 353). Elas significam também um importante pano de fundo para a emergência do protesto e, até, para a possibilidade dos jovens se assumirem, num contexto muito particular como o que aconteceu em 2011, como os intérpretes de um descontentamento geral. Como argumenta Dubet (2008: 374), "por falta de perspectivas de futuro, as jovens gerações têm uma visão do mundo que se aproxima da das classes dominadas".

Apesar de ter uma correspondência com os dados, a força da canção dos Deolinda não estará tanto no facto de identificar as dificuldades do acesso ao trabalho mas sim no modo como exprimiu as consequências dessa precariedade laboral em termos de existência quotidiana, isto é, a forma como deu voz a uma "geração casinha dos pais" que "está sempre a adiar" os seus projetos. De facto, a inserção subalterna no mercado laboral compromete a autonomia e exige disposições marcadas pela necessidade de adaptação permanente, por um "novo contrato psicológico" baseado em compromissos de curto prazo (Lewis et al., 2002), que limita fortemente a emergência de preocupações coletivas e de projetos para além de um curto horizonte temporal.

De acordo com um estudo da Eurostat (2010), Portugal é um dos países onde a saída de casa dos pais se faz mais tardiamente - cerca de $60 \%$ dos jovens adultos entre os 18 e os 34 anos vivem na casa dos seus pais, enquanto que nos países nórdicos (Dinamarca, Suécia e Finlândia) essa percentagem fica-se pelos $20 \%$. Entre os fatores que explicam este "prolongamento da adolescência" encontram-se a dificuldade de acesso à habitação, o desemprego e a precariedade e a necessidade de apoiar as suas famílias. Como demonstram Alves et al. (2011), a dependência em relação aos ascendentes mantém-se mesmo nas situações em que já existe autonomia residencial ${ }^{14}$. A "família-providência", que em Portugal tem ajudado a suprir as carências do Estado Social, pode contudo começar a ter dificuldades, com o agravamento da crise, em cumprir essa tarefa (Santos, 2011: 76 -77).

Pressente-se, então, o paradoxo: a situação da juventude, frequentemente considerada pelos discursos oficiais como "o futuro", é marcada afinal pela erosão da ideia de futuro enquanto direção para o progresso. Na verdade, e apesar das qualificações, os diplomas e a escolarização não garantem hoje o acesso à "classe média" com que a maioria parece querer identificar -se (Estanque, 2003; Estanque, 2012) ${ }^{15} \mathrm{e}$ a condições de vida melhores do que tinham as classes populares no anterior regime do capitalismo.

\section{Fragmentação estatutária e conflitos de gerações}

É evidente que há diferenciações internas dentro da juventude. Apesar de, entre $2011 \mathrm{e}$ 2012, ter havido um acréscimo de 49,5\% no desemprego dos diplomados do ensino superior (IEFP, 2012), as transições dos jovens para a vida adulta em Portugal são marcadamente divergentes e a escolaridade joga um papel importante, sendo a qualificação um fator de proteção relativa ${ }^{16}$. Para usar a tipologia de Guerreiro e Abrantes (2007), há que distinguir transições profissionais, lúdicas, experimentais, progressivas, antecipadas, precárias e desestruturantes. Entre o pólo dos jovens altamente qualificados dos sectores de ponta com maior crescimento económico e os que acumulam factores de discriminação, há um mundo de diferenças, estando estes últimos, muitos vezes, marcados por percursos altamente desqualificantes (nomeadamente na escola) e por isso 
mesmo condenados a um processo de relegação estrutural e de invalidação irreversível que os afasta do contacto com o mundo do trabalho formal ou do trabalho com direitos e os empurra para a busca de "alternativas ao trabalho", designadamente na economia informal ou em expedientes ligados a atividades ilícitas (Castel, 2009).

Contudo, o facto de se enunciar o fenómeno como o de uma "geração", com todos os problemas sociológicos que coloca, tem um fundamento. As formas de trabalho temporário, de emprego assistido, de contratos a termo e de falso trabalho autónomo, mesmo quando não são ainda dominantes para o conjunto da sociedade, são cada vez mais uma passagem obrigatória para os que entram na vida ativa, daí serem tão típicas das experiências dos jovens ${ }^{17}$. Esse elemento de "tipicidade juvenil" deve -se sobretudo, mais do que à variável idade em si mesma, à circunstância de os jovens representarem a maioria dos que entram agora no mercado de trabalho, deparando -se com as características e com as dificuldades das formas mais recentes do modelo de trabalho e sendo quem mais se subordina às novas políticas de gestão da mão-de-obra e de organização do mundo produtivo (Castel, 2009: 140). Ou seja, os jovens são o grupo no qual é mais marcante uma relação cada vez mais problemática e aleatória com o trabalho, transformando-se o facto de constituírem os "novos recrutamentos", para uma parte significativa deles, num verdadeiro handicap, sobretudo num contexto de profundas alterações no modo de regulação do trabalho - onde muitas vezes são autênticas "cobaias das transformações que se pretendem introduzir" (CIES/CGTP -IN, 2011).

A narrativa geracional, que aparece na canção "Parva que Sou", teve o efeito político de criar uma identidade comum - a "Geração à Rasca" - que se transformou em mobilização social no 12 de Março. Mas essa narrativa pode também contribuir para ocultar as diferentes juventudes que existem e para criar uma grelha de leitura do conflito social em torno de uma "clivagem geracional" que explicaria as transformações em curso. Ao longo deste último ano, aliás, o campo liberal tem utilizado precisamente a ideia de uma "guerra de gerações" para legitimar um conjunto de propostas que vão no sentido de uma precarização crescente da legislação laboral em Portugal ${ }^{18}$. Neste caso, o argumento é que a explicação para o desemprego e a precariedade dos mais novos está no facto de o mercado de trabalho estar "bloqueado" à sua entrada em virtude da "ditadura dos direitos adquiridos" que, por via da suposta rigidez do nosso enquadramento legal, protegeria os que "já têm emprego". Mas será mesmo assim? O que nos diz a sociologia? E a experiência da "Geração à Rasca"?

Para tentar contrariar o discurso do "conflito de gerações", os organizadores do 12 de Março passaram a falar, nos dias anteriores à manifestação, das várias "gerações à rasca" 19. Essa expressão teve o efeito de criar uma dinâmica intergeracional para o protesto - ou seja, teve uma intenção estratégica de buscar alianças com outros setores "à rasca" na sociedade portuguesa. Esse tipo de convergências continuou, depois do próprio dia, em ações conjuntas que o Movimento 12 de Março (M12M) ${ }^{20}$ desenvolveu com colectivos de trabalhadores precários mas também com a Associação 25 de Abril ou com a CGTP, cujos protagonistas e dirigentes pertencem precisamente à geração que, no discurso liberal, bloquearia "o acesso dos mais jovens ao mercado de trabalho". Essas escolhas do M12M não impediram contudo que a narrativa do conflito de gerações tenha feito o seu caminho no senso comum, e isso mesmo foi possível verificar nas mensagens que alguns participantes do protesto levaram para a rua: "fim aos direitos adquiridos", "simplificar as leis laborais, atualmente prejudiciais para quem nos dá trabalho", "lugar ao mérito sobre a antiguidade", "rua com quem tira lugar a quem quer trabalhar". 
das razões que explica a capacidade de difusão dessa representação é a associação entre a "fragmentação estatutária" (Marques, 2009) e a idade. No caso estudado por Beaud e Pialoux (1999), a destruição de antigas solidariedades operárias e das identidades construídas a partir do coletivo de trabalho faz-se, no contexto industrial, pelo estabelecimento de uma linha de fratura geracional entre trabalhadores permanentes e temporários. Acontece que essa fragmentação, mesmo que por vezes possa ter contornos geracionais, é na realidade uma tendência da precarização geral e uma estratégia para a diversificação da condição salarial, fazendo coexistir indivíduos que têm o mesmo trabalho, as mesmas tarefas, mas beneficiam de estatutos muito diferentes. Esta diversificação de estatutos e de empregadores para os trabalhadores da mesma empresa visou estilhaçar o coletivo de trabalho, tornando mais difícil a ação colectiva e a representação organizada dos trabalhadores (Beaud, 2008: 569). Essa dinâmica de descoletivização não apenas "desestabiliza os estáveis" como, fazendo-o, quebra as solidariedades intracategoriais típicas da sociedade salarial. No fundo, vira "um contra o outro": a pressão para a adaptabilidade, para a flexibilidade, a ameaça do desemprego e a fragilidade dos vínculos conduz a um acentuar da concorrência entre iguais, como se o trabalhador fosse impelido a mobilizar -se apenas individualmente para fazer face aos desafios do seu próprio percurso e sobrevivência.

A ameaça permanente do desemprego e uma relação com o mercado de trabalho marcada pela insegurança, pela intermitência, pela descontinuidade e pela transitoriedade significa que mais dificilmente se estruturam identidades estáveis a partir do local de trabalho e que muitas vezes se desenvolve um individualismo de resignação mais ou menos ressentido (Estanque, 2005). A precariedade é um dos fatores que explica o recuo das taxas de sindicalização, em particular entre os jovens e, por isso mesmo, ela constitui um desafio efetivo às formas de ação e organização tradicionais dos trabalhadores. A fragmentação no mundo produtivo e a cultura do individualismo é muitas vezes hostil à militância, sobretudo nos contextos em que o envolvimento ou a adesão a um colectivo marca e "estigmatiza" um indivíduo, reduz o seu campo de possíveis, afeta a sua identidade e nos casos em que existem desajustamentos entre a esfera militante e a esfera profissional, amical e familiar (Sawicki e Siméant, 2009: 105). A escassez de redes afetivas e sociais fortes no contexto do trabalho leva à alteração das condições e das modalidades de participação, nomeadamente dos jovens, mas isso não significa necessariamente um desaparecimento da possibilidade de mobilização coletiva. O ano de 2011 encarregou-se de o demonstrar.

\section{6. "Joga comigo um jogo novo"21: movimentos, sindicatos e o regresso das classes}

31 A capacidade de renovação dos sindicatos, as relações que consigam estabelecer com outras formas de organização social, as alianças que forem capazes de travar com outros atores e movimentos sociais, o papel das redes sociais e do ciberespaço e as articulações transnacionais são alguns dos desafios que se colocam hoje ao movimento dos trabalhadores num contexto de precarização (Estanque e Costa, 2011).

Os movimentos de trabalhadores precários - onde se incluem, por exemplo, a Plataforma dos Intermitentes, o Fartos d'Estes Recibos Verdes (FERVE), os Precários Inflexíveis, a Associação de Bolseiros de Investigação Científica, o MayDay ou a Maldita Arquitectura - 
têm trazido contributos muito importantes para pensar a questão da precariedade e das modalidades de ação colectiva que em torno dela podem surgir. Como defendi noutro lugar (Soeiro, 2009), estes movimentos conseguiram criar uma identificação identitária em torno da condição de precariedade e estruturar a partir dela comunidades militantes. Ao fazê-lo, colocaram com sucesso a questão da precariedade na agenda mediática e política, constituindo-se em muitos casos como interlocutores do "precariado" para a sociedade. A análise das suas modalidades de ação mostra que a comunicação, a produção de conteúdos multimédia (alguns com efeito viral) e o recurso às novas tecnologias são absolutamente centrais. A utilização criativa do ciberespaço permitiu amplificar a sua mensagem, criar rede, utilizar o espaço virtual como lugar de encontro e aglutinação, em particular nos contextos em que isso é difícil no espaço físico. As novas tecnologias têm servido para a disputa online da informação e das leituras da realidade mas a mobilização também se faz offl ine. Um bom exemplo é a Iniciativa Legislativa Cidadã ${ }^{22}$ pela "Lei Contra a Precariedade", para a qual os seus promotores recolheram presencialmente mais de 35 mil assinaturas. Iniciativa semelhante, embora menos extensa, tinha já acontecido a propósito da petição "Antes da Dívida temos Direitos" ${ }^{23}$, que gerou uma campanha muito para além da internet.

Estes movimentos, cuja composição social é a inversa da do movimento sindical (mais jovens, muito escolarizados, forte presença de mulheres), têm combinado formas mais clássicas de intervenção política (a petição, a manifestação de rua) com formas mais criativas e transgressivas de ação (invasão de call-centres, interrupção de eventos...), tentando articular luta e festa, horizontalidade e organização. A lógica do polienvolvimento que caracteriza os seus protagonistas construiu uma relação com o movimento sindical que é relevante, mesmo quando é de cooperação tensa e atravessada pelas diferenças de linguagem, de hegemonia política, de culturas de classe que persistem.

A "Geração à Rasca" e as mobilizações de 2011 e de $2012^{24}$, trouxeram contudo um novo elemento e criaram um novo pólo de organização do protesto. Como salienta Santos (2011:106), elas evidenciaram que "as formas de organização de interesses nas sociedades contemporâneas (partidos, sindicatos, movimentos sociais, ONGs) não captam senão iniciativa uma pequena faixa da cidadania potencialmente ativa". Alguns destes movimentos foram, para muita gente, lutas fundacionais e constituíram -se como íman de vários ativismos. Apesar da exuberância das diferenças, podemos identificar alguns elementos comuns na dinâmica que vai dos Indignados ao movimento Occupy: a forte presença de jovens, nomeadamente escolarizados - precários, desempregados e estudantes; uma certa tendência assembleária; a utilização das redes sociais e da comunicação em rede; a articulação de uma experiência colectiva feita de polifonia e da coexistência de expressões individuais; a presença do testemunho biográfico; a experimentação de formas de organização e de compromisso que recusam a delegação.

Não pretendo aqui reproduzir os argumentos simplistas segundo os quais estamos perante a oposição entre o "militantismo distanciado" de hoje e o "militantismo total" do passado (Ion, 1997). Também não me parece ser rigorosa a ideia de que estas formas de ativismo são absolutamente novas. Muitas das características não são, de facto, inéditas. Mas é verdade que as formas de compromisso mudaram, entre outras razões, porque mudou a própria condição juvenil. O chamado "prolongamento da adolescência", a maior escolarização, o desemprego e a precariedade, a alteração das referências políticas e a debilidade de projetos alternativos ao capitalismo marcam os percursos da juventude de 
hoje e isso altera também a sua relação com o ativismo social e com a política - ou seja, a sua forma de militância. A valorização de grupos mais informais - estruturados a partir de relações sociais espontâneas - em detrimento de grupos mais institucionais, ligados a entidades formais e oficiais (Galland, 1996), a desconfiança relativamente às instituições em geral e à política em particular, mas também o "eclipse da razão estratégica" (Bensaïd, 2008), parecem ser algumas das tensões que atravessam estas mobilizações.

Contra a inevitabilidade de um futuro comandado pela precarização, temos visto surgir, ao longo dos últimos anos, formas de expressão, lutas sociais e novos sujeitos políticos em torno da questão do trabalho. Na opinião de Boltanski (2008), este "regresso das classes sociais" à luta política não se fará necessariamente recuperando as formas anteriores da sua existência e representação. 0 sucesso de um campo social alternativo à lógica da precarização dependerá provavelmente da capacidade que tiverem sindicatos, partidos, movimentos sociais, sociedade civil não organizada, coletivos e associações para pôr em comunicação as suas razões e as suas práticas e para aprenderem uns com os outros. Sem certezas consoladoras, resta à sociologia fazer também parte dessa descoberta, para que o presente seja o avesso de uma eterna precariedade.

\section{BIBLIOGRAFIA}

ALVES, Nuno de Almeida; CANTANTE, Frederico; BAPTISTA, Inês; CARMO, Renato Miguel (2011), Jovens em Transições Precárias. Trabalho, quotidiano e futuro. Lisboa: Editora Mundos Sociais.

ANTUNES, Ricardo (2008), "Desenhando a nova morfologia do trabalho: as múltiplas formas de degradação do trabalho", in Revista Critica de Ciências Sociais, Dezembro de 2008, Coimbra,

CES. BEAUD, Stéphane; CONFAVREUX, Joseph; LINDGAARD, Jade (dir.) (2008), La France Invisible, Paris: La Découverte.

BEAUD, Stéphane e PIALOUX, Michel (1999), Retour sur la Condition Ouvrière, Paris: Fayard.

BECK, Ulrich (1992), Risk Society: Towards a New Modernity, Londres: Sage Publications.

BENSAÏD, Daniel (2008), Éloge de la politique profane, Paris: Albin Michel.

BOLTANSKI, Luc (2008), Rendre la realité Inacceptable, Paris: Démopolis

BOLTANSKI, Luc; CHIAPELLO, Ève (1999), Le Nouvel Esprit du Capitalisme, Paris: Gallimard.

CASTEL, Robert (2009), La Montée des Incertitudes. Travail, protections, statu de l'individu, Paris: Seuil.

CHAUVEL, Louis (2008), “L'horizon obscurci des jeunes générations”, in Stéphane Beaud, Joseph Confavreux e Jade Lindgaard (dir.), La France Invisible, Paris: La Découverte.

CHAUVEL, Louis (2006), Les Classes Moyennes à la derive, Paris: Seuil.

CHOMSKY, Noam (2012), Occupy, Londres: Penguin Books.

CIES/CGTP -IN (2011), “O Emprego e o Estatuto Social dos Jovens”, disponível em: http:// www.cgtp. pt/images/stories/imagens/2011/12/emprego_estatuto_jovens.pdf [consultado em 20 de Janeiro de 2012] 
DAVIS, Mike (2012), Soyez Réalistes, Demandez l’Impossible, Paris: Les Prairies Ordinaires.

DUBET, François, (2008), “Déclassement du diplôme et dévalorisation des métiers”, in Stéphane Beaud, Joseph Confavreux e Jade Lindgaard (dir.), La France Invisible, Paris: La Découverte

ESTANQUE, Elísio; COSTA, Hermes (2011), o Sindicalismo Português e a Nova Questão Social. Crise ou Renovação?, Coimbra: Almedina.

ESTANQUE, Elísio (2005), “Classes, precariedade e ressentimento: mudanças no mundo laboral e novas desigualdades sociais", oficina do CES, n. 238 .

ESTANQUE, Elísio (2003), “O efeito classe média: desigualdades e oportunidades no limiar do século XXI", in M. Villaverde Cabral et al., Desigualdades Sociais e Percepções de Justiça, Lisboa, ICS/ ISSP, $69-105$.

EUROSTAT (2010), “51 million young EU adults lived with their parent(s) in 2008”, Statistics in focus 50/2010, disponível em www.epp.eurostat.ec.europa.eu [consultado em 14 de Janeiro de 2012]

FERREIRA, António Casimiro (2009), Da Sociedade Precária à Sociedade Digna. Balanço da Evolução Social em Portugal 2003 -2008. Relatório Preliminar para a UGT.

GALLAND, Olivier (1996), Les Jeunes, Paris: La Découverte.

GOUX, Dominique e MAURIN, Éric (2012), Les Nouvelles Classes Moyennes, Paris: Seuil.

GUERREIRO, Maria das Dores; ABRANTES, Pedro (2007), Transições Incertas. Os jovens Perante o

Trabalho e a Familia, Lisboa: CITE.

IEFP (2012), Informação Mensal do Mercado de Emprego, no 7, julho de 2012.

INE (2010), Homens e Mulheres em Portugal 2010, INE, disponível em www.ine.pt [consutado em 23 de Novembro de 2011]

ION, Jacques (1997), La fin des militants?, Paris. L'Atelier.

KOVÁCS, Ilona (org.) (2005), Flexibilidade de Emprego: riscos e oportunidades, Oeiras: Celta Editora.

LEWIS, Suzan; SMITHSON, Janet e KUGELBERG, Clarissa (2002), "Into work: job insecurity and changing psychological contracts", em Julia Brannen, Suzan Lewis, Ann Nilsen e Janet Smithson (orgs.), Young Europeans, Work and Family, Londres: Routledge.

MARQUES, Ana Paula (2009), "Novas" legitimidades de segmentação do mercado de trabalho de jovens diplomados. In Revista Portuguesa de Educação, 22, pp 88 -115.

MARQUES, Duarte (2012), DAR I série №.61/XII/1 2012.01.20 (pág. 25 -36), disponível em www.parlamento.pt [consultado em 26 de junho de 2012].

OIT (2012), Global Employement Trends for Youth 2012, disponível em www.ilo.org [consultado em 19 de setembro de 2012]

OIT (2011), Global Employement Trends for Youth update, disponível em www.ilo.org [consultado em 29 de Janeiro de 2012]

OIT (2010), Global Employement Trends for Youth 2010, disponível em www.ilo.org [consultado em 29 de Janeiro de 2012]

OLIVEIRA, Luísa; CARVALHO, Helena; VELOSO, Luísa (2011), "Formas Atípicas de Emprego juvenil na União Europeia”, in Sociologia, Problemas e Práticas, n. 66: 27 -48.

PAIS, José Machado (2001), Ganchos, Tachos e Biscates. Jovens, Trabalho e Futuro, Porto: Âmbar. 
PAUGAM, Serge (2000), Le Salarié de la Précarité, Paris: Presses Universitaires de France.

PINTO, José Madureira (2005), "Precarização e relações de sentido no espaço social do trabalho", comunicação no Encontro Científico Internacional Trabalho, Emprego e Precariedade Laboral, disponível in www.maydayporto.blogspot.com [consultado em 8 de Março de 2009]

POLANYI, Karl (2012), A Grande Transformação, Lisboa: Edições 70.

RODRIGUES, Eduardo Vítor (2010), Escassos Caminhos: os processos de imobilização social dos beneficiários do RMG/RSI, Porto: Afrontamento.

SANTOS, Boaventura (2011), Portugal. Ensaio contra a autoflagelação, Coimbra: Almedina.

SAWICKI, Frédéric, SIMÉANT, Johanna (2009), "Décloisonner la sociologie de l'engagement militant. Note critique sur quelques tendances recentes des travaux français”, in Sociologie du Travail, n.51.

SOEIRO, José (2009), "Hipóteses sobre os Movimentos de Precários em Portugal”, in AAVV, Dois anos a FERVER: retratos da luta, balanço da precariedade, Porto: Afrontamento.

TAIBO, Carlos (2011), El 15 -M en sessenta preguntas, Madrid: Los Libros de la Catarata.

VIEJO, Raimundo (ed) (2011), Les raons dels indignats, Barcelona: Portic.

SEDDIK, Youssef (2011), Unissons-nous. Des révolutions árabes aux indignés. La Tour d'Aigues: Éditions de l'Aube

\section{NOTAS}

1. Os Deolinda são um projeto musical português, nascido em 2006, com três álbuns editados até ao presente. O segundo disco do grupo, intitulado "Dois Selos e Um Carimbo", cujo single de apresentação, tendo por tema "Um Contra o Outro", gozou de um enorme sucesso. Com "Parva Que Sou", a música dos Deolinda ganhou um inesperado protagonismo não apenas na cena musical mas também no campo social e político.

2. Disponível em www.youtube.com/watch?v=f8lo82tXbWU\&feature=player_embedded

3. A manifestação da "Geração à Rasca" foi um protesto que teve lugar no dia 12 de março de 2011, iniciado por quatro jovens - Alexandre Carvalho, António Frazão, João Labrincha e Paula Gil - através de um evento do Facebook difundido profusamente por meio das redes sociais. No manifesto que o convocou, a condição desta "geração" era identificada através das seguintes categorias: “desempregados, 'quinhentoseuristas' e outros mal remunerados, escravos disfarçados, subcontratados, contratados a prazo, falsos trabalhadores independentes, trabalhadores intermitentes, estagiários, bolseiros, trabalhadores-estudantes, estudantes, mães, pais e filhos de Portugal". o protesto servia, segundo o mesmo documento, "para que todos os responsáveis pela nossa atual situação de incerteza - políticos, empregadores e nós mesmos atuem em conjunto para uma alteração rápida desta realidade, que se tornou insustentável”.

4. Para uma análise crítica dos processos que tiveram lugar na Tunísia e no Egito, bem como do efeito de contaminação que produziram, cf. Youssef Seddik (2011), Unissons-nous. Des révolutions árabes aux indignés. La Tour d'Aigues, Éditions de l'Aube.

5. Noam Chomsky, um dos intelectuais mais marcantes do panorama crítico norte -americano, considerou o movimento Occupy, nascido em meados de janeiro no coração do distrito financeiro de Nova Iorque, como "a primeira resposta pública massiva a 30 anos de guerra de classe". Para uma análise interessanteacerca dos impactos e dos desafios colocados por esta mobilização, cf. Noam Chmosky (2012). 
6. A Grande Transformação é aliás o título da obra mais conhecida de Karl Polanyi, publicada em 1944, e agora editada em Portugal (Polanyi, 2012).

7. Cf., por exemplo, o trabalho desenvolvido por Eduardo Vítor Rodrigues (2010).

8. O trabalho temporário deve chegar hoje a cerca de meio milhão de trabalhadores no nosso país. Os números foram apresentados por Marcelino Pena Costa, presidente da Associação Portuguesa das Empresas do Sector Privado de Emprego (APESPE), ao jornal SOL na sua edição de 18 de Fevereiro de 2011, e indicam

9. Estas mensagens foram entregues no Parlamento e encontram -se disponíveis para consulta pública no arquivo do Presidente da Assembleia da República.

10. No caso dos jovens com menos qualificações, esse período de espera alonga -se até aos 26 meses; no caso dos jovens licenciados, ele reduz -se aos 9,6 meses (CIES/CGTP, 2011).

11. Em $2009 / 2010,30,6 \%$ dos jovens em idade de frequentar o ensino superior frequentavam este tipo de ensino.

12. Para o mesmo período, a taxa de desemprego em Portugal, segundo o Eurostat, era de $15,7 \%$.

Cf. Em http://epp.eurostat.ec.europa.eu.

13. Qualquer uma destas mensagens encontra -se nas folhas que os manifestantes utilizaram nas ruas e que

foram posteriormente entregues aos deputados da Assembleia da República.

14. Estamos a falar, por exemplo, de apoio ao nível de bens alimentares, das despesas relacionadas com os filhos ou outras. Em qualquer uma das situações, as estratégias de autonomia diferem de acordo com variáveis estruturais, como o género, a ocupação profissional e respetiva remuneração, os capitais escolares ou a classe de origem. Os jovens mais qualificados têm posições de autonomia maior e aqueles que são oriundos de famílias com maiores recursos encontram nos pais a possibilidade de apoiar o processo de transição para a vida adulta através do pagamento de despesas como casa, carro ou propinas. Também ao nível do capital social, as origens familiares podem fazer toda a diferença (Alves et al. 2011)

15. O facto de a "classe média urbana" se assumir como um referente simbólico na percepção de vastos setores da classe trabalhadora, amplia -a subjetivamente para lá dos seus limites objetivos e do seu peso demográfico (Estanque 2012: 81 -84)

16. Como defende o estudo de Alves et al. (2011: 36), existe em Portugal uma associação particularmente forte "entre qualificação académica e enquadramento ocupacional", dando origem a uma forte hierarquização credencialista. Esta ocorre, contudo, num contexto em que o emprego disponível não absorve as qualificações, fazendo com que uma parte da população mais credenciada só tenha como oportunidade funções menos qualificadas, ocupando postos de trabalhos intermédios, o que funciona como forma de compressão salarial e pressão sobre os que detêm qualificações intermédias, que ocupam postos desqualificados.

Uma das explicações para o desemprego dos jovens licenciados relaciona -se com o efeito combinado de um mercado de trabalho com poucos empregos qualificados, do estancamento das admissões na Administração Pública (tradicionalmente, o maior empregador de pessoas com ensino superior) e dificuldades associadas a algumas áreas de formação em particular (nomeadamente ciências empresariais e humanidades).

17. Um estudo comparativo publicado recentemente conclui que "a geração dos mais jovens (15 -24 anos) é, de longe, a mais afectada pelo trabalho temporário em todos os países da UE", evidenciando -se "uma tendência para um agravamento do fenómeno de geração para geração, sobretudo nos países europeus nos quais o fenómeno tem um peso relevante (Portugal e Espanha)" (Oliveira, Carvalho e Veloso, 2011: 41 -42).

18. Este tipo de tese tem sido defendida, no campo político, por exemplo, pela Juventude Social Democrata. Numa intervenção parlamentar que suscitou polémica, o deputado Duarte Marques, líder desta organização juvenil, comentou o acordo da concertação social nos seguintes termos: "Pagámos os nossos benefícios com o dinheiro dos nossos próprios filhos, sustentando o nosso 
vício através da penhora das gerações futuras(...) Apesar de já vivermos há muitos anos em democracia, persiste ainda uma ditadura com a qual não contávamos: a ditadura dos direitos adquiridos, a ditadura das mesmas classes, sempre protegidas, a ditadura do mercado fechado, em que os jovens, sobretudo os mais jovens, estavam proibidos de entrar. (...) Com este acordo, é possível acreditar num contrato geracional em que os mais velhos abdiquem de alguma coisa para que os mais jovens tenham coisa alguma" (Marques, 2012).

19. Curiosamente, entre as folhas entregues pelos organizadores do protesto, contam-se muitas dezenas assinadas por "mães" e "avós", bem como por "pensionistas" e outras categorias.

20. O Movimento 12 de Março foi um coletivo constituído na sequência do protesto da "Geração à Rasca", cujos objetivos passam pela promoção do "reforço da democracia no trabalho, na economia, na política, na cultura, na educação e nas consciências" e pela ativação de modalidades e iniciativas de "democracia participativa".

21. Verso da canção dos Deolinda, "Um contra o outro".

22. A Lei Contra a Precariedade é uma iniciativa legislativa de cidadãos lançada pelos Precários Inflexíveis, Movimento 12 de Março, Ferve e Intermitentes do Espetáculo. O seu objetivo é, parafraseando o preâmbulo da proposta, introduzir "mecanismos legais de modo a evitar a perpetuação das formas atípicas e injustas de trabalho, incidindo sobre três vectores fundamentais da degradação das relações laborais com prejuízo claro para o lado do trabalhador: os falsos recibos verdes, a contratação a prazo e o trabalho temporário". o sítio web desta iniciativa pode ser consultado em www.leicontraaprecariedade.net.

23. campanha "Antes da Dívida Temos Direito" desenvolveu -se em torno de uma petição, cujo objetivo era utilizar o momento da cobrança da dívida à segurança social dos trabalhadores independentes como um mecanismo de fiscalização sobre os termos em que essa dívida havia sido contraída. Na prática, a iniciativa pretendia que, caso a dívida tivesse sido contraída por trabalhadores a "falso recibo verde", a cobrança fosse feita não apenas ao trabalhador mas também à entidade patronal e que se despoletasse intervenção das autoridades competentes com vista à celebração de um contrato de trabalho. A petição foi levada ao plenário da Assembleia da República, tendo dado origem a iniciativas legislativas que acabariam por ser chumbadas. Mais informação pode ser encontrada em www.antesdadividatemosdireitos.org.

24. Um grupo de 29 cidadãos lançou uma convocatória nas redes sociais para uma manifestação nesse dia sob o lema "Que se lixe a Troika! Queremos as nossas vidas de volta!". No manifesto da iniciativa pode ler-se um diagnóstico muito crítico sobre as escolhas políticas recentes: "depois de mais um ano de austeridade sob intervenção externa, as nossas perspectivas, as perspectivas da maioria das pessoas que vivem em Portugal, são cada vez piores" porque " a austeridade que nos impõem e que nos destrói a dignidade e a vida não funciona e destrói a democracia”. 0 apelo à insubmissão cidadã - "se nos querem vergar e forçar a aceitar o desemprego, a precariedade e a desigualdade como modo de vida, responderemos com a força da democracia, da liberdade, da mobilização e da luta" - acabou por ter eco e materializar-se em mais de 30 manifestações que terão juntado cerca de um milhão de pessoas em várias cidades portuguesas.

\section{RESUMOS}

Os processos de precarização do trabalho são um elemento fundamental da "grande transformação" em curso no regime do capitalismo (Castel, 2009). Em Portugal, esses processos assumem características particulares e têm uma incidência forte na juventude. A inserção laboral 
dos jovens caracteriza-se por ser longa, penosa e complexa, confi gurando a emergência de um "geração low cost". Estas mudanças criam também novos segmentos de classe e uma juventude crescentemente escolarizada, cujo abismo entre expectativas e oportunidades pode ser gerador de ressentimento e revolta. Tomando como pretexto o protesto da "Geração à Rasca", este artigo pretende avançar elementos para compreender o fenómeno.

The development of precarious forms of work is a key element of the "great transformation" underway in the regime of capitalism (Castel, 2009). In Portugal, it has assumed particular features and has had a strong impact on young people. The employability of young people is a long, painful and complex process, indicating the emergence of a «low-cost generation» (Chauvel, 2008), victim of a double disqualification. These changes have also created new class segments and an increasingly educated youth whose gap between expectations and opportunities may generate phenomena of resentment and rebellion. We have addressed this dynamic of precariousness and the forms of collective action that have emerged.

Les processus de précarisation du travail sont un élément clé de la " grande transformation » en cours dans le régime capitaliste (Castel, 2009). Au Portugal, ils assument des caractéristiques particulières et atteignent très fortement les jeunes. L'insertion des jeunes sur le marché de travail est longue, douloureuse et complexe ; elle conduit à l'émergence d'une génération « low cost » (Chauvel, 2008). Ces changements créent également de nouveaux segments de classes et une jeunesse de plus en plus instruite, pour laquelle l'écart entre les attentes et les opportunités peut générer du ressentiment et de la révolte. En partant de l'analyse de la manifestation " Geração à rasca » (génération en difficulté), cet article vise à avancer des éléments qui permettent de comprendre le phénomène.

\section{ÍNDICE}

Keywords: precarious forms of work, labour, youth, collective action

Mots-clés: précarisation, travail, jeunesse, action collective

Palavras-chave: precarização, trabalho, juventude, ação colectiva

\section{AUTOR}

\section{JOSÉ SOEIRO}

Faculdade de Economia da Universidade de Coimbra/CES, ziro_s@yahoo.com 